Research Article

\title{
Sex hormones alter the effect of aspirin on bleeding
}

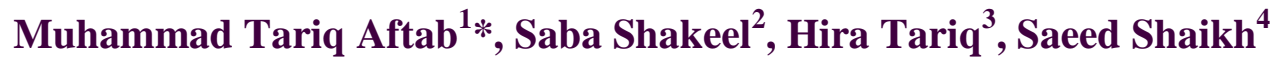

${ }^{1}$ Department of Pharmacology and

Therapeutics, Karachi Medical and Dental College, North Nazimabad, Karachi, Pakistan

${ }^{2}$ Sindh Medical College, Dow University of Health Sciences, Karachi, Pakistan

${ }^{3}$ Dr. Ishrat-ul-Ebad Khan Institute of Oral Health Sciences, Dow University of Health Sciences, Karachi, Pakistan

${ }^{4}$ Baqai Medical University, Karachi, Pakistan

Received: 17 July 2013

Accepted: 4 August 2013

\section{*Correspondence to:}

Dr. Muhammad Tariq Aftab,

Email: drtariqaftab@yahoo.com

(C) 2013 Aftab MT et al. This is an open-access article distributed under the terms of the Creative Commons Attribution NonCommercial License, which permits unrestricted non-commercial use, distribution, and reproduction in any medium, provided the original work is properly cited.

\begin{abstract}
Background: Interaction of aspirin and sex hormones was investigated through bleeding time.

Methods: Bleeding time in 32 males and 105 unmarried females with previous 6 normal menstrual cycles and all aged between 18 to 21 years was found by Duke's method before and after 2 hours of aspirin administration. Phase of menstrual cycle of each female was determined by present menstrual history.

Results: Bleeding time in 32 male was $69.33 \pm 4.94$ seconds and in 105 female was $73.03 \pm 1.89$ seconds which were not statistically different $(\mathrm{P}>0.05)$. This time was increased to $107.66 \pm 4.76$ seconds in males and 113.65 \pm 3.73 seconds in females after aspirin administration which were statistically different $(\mathrm{P}<0.05)$. The response in males was relatively greater $(\mathrm{P}<0.0005)$ as compared to females $(\mathrm{P}<0.0025)$. Among females, 44 were in follicular phase while 29 were in luteal phase as per their menstrual histories. Bleeding time in females in Follicular phase was increased from $70.22 \pm 2.90$ seconds to $109.65 \pm 3.82$ seconds and in females in luteal phase from $81.13 \pm 4.26$ seconds to $117.95 \pm 7.49$ after aspirin administration. The statistics of bleeding time in follicular and luteal Phases shows a statistically significant $(\mathrm{P}<0.05)$ difference before aspirin but non-significant $(\mathrm{P}>0.05)$ difference after aspirin administration with a greater effect in Follicular phase probably due to estradiol.

Conclusion: Males respond to aspirin more as compared to females which is likely the effect of the drug and testosterone interaction. Similarly females in the follicular phase respond to aspirin more as compared to females in the luteal phase which may be a result of interaction of estrogen and aspirin.
\end{abstract}

Keywords: Sex hormones, Aspirin, Bleeding time

\section{INTRODUCTION}

Hormones and drugs interact with each other as demonstrated by different responses of drugs in variety of individuals. These can either be direct, when drugs and hormones have common locus of action or indirect that is, by modifying some other factors, for example pharmacokinetics of a drug. These phenomena might be the reason behind the gender related dissimilarities in drug responses.

Aspirin which is acetyl-salicylic acid, is the most commonly used antiplatelet drug in the prevention of cardiovascular diseases. ${ }^{1}$ The use is attributed to its effect as irreversible inhibitor of enzymes cyclo-oxygenases, COX-1 and COX-2. Owing to its irreversible inhibition of COX-1 in platelets and decreasing a potent vasoconstrictor and platelet aggregator thromboxane $(\mathrm{TX}-\mathrm{A} 2)^{2}$, aspirin increases bleeding time. Thus bleeding time is considered as the measure of response to aspirin.

Testosterone is the major hormone in a male, while estrogen and progesterone are highly important in a female body. Since, these hormones effect bleeding tendency, they can be the reason of gender related discrepancies in responses to aspirin. Such a relationship is investigated in our study. 


\section{METHODS}

137 healthy medical college undergraduate volunteers, 105 females and 32 males were randomly recruited for this study. All the participants gave written, informed consent before participation in the study.

A performa was filled by each volunteer, providing information about their name, age and sex.

Stage of menstrual cycle of each female was also determined using a structured interview.

Bleeding time was determined by Duke's method and noted.

The study protocol was approved by the university ethical committee.

SPSS version was used for statistical analysis.

\section{RESULTS}

Table 1 shows bleeding time in male and female volunteers. Mean bleeding time in 32 male volunteers is $69.33 \pm 4.94$ (mean \pm SEM), while in 105 females is $73.03 \pm 1.89$ (mean \pm SEM). Statistically insignificant difference $(\mathrm{P}>0.05)$ exists between the two.

Table 1: Bleeding time before aspirin administration in male and female.

\begin{tabular}{|lll|}
\hline Sex & Bleeding time & Significance \\
\cline { 1 - 2 } Male & $69.33 \pm 4.94(32) *$ & \\
\cline { 1 - 2 } Female & $73.03 \pm 1.89(105)$ & \\
\hline
\end{tabular}

* Mean \pm SEM (Number of volunteers)

Table 2 depicts the effect of aspirin on bleeding time of different genders. Bleeding time in 32 male volunteers is $107.66 \pm 4.76$ (mean \pm SEM) and in 105 females is $113.65 \pm 3.73$ (mean \pm SEM) after aspirin administration. There is a statistically significant difference $(\mathrm{P}<0.05)$.

Table 2: Bleeding time after aspirin administration in male and female.

\begin{tabular}{|lll|}
\hline Sex & Bleeding time & Significance \\
\cline { 1 - 2 } Male & $107.66 \pm 4.76(32)^{*}$ & \\
\cline { 1 - 2 } Female & $113.65 \pm 0.05$ \\
\hline
\end{tabular}

* Mean \pm SEM (Number of volunteers)

Table 3 shows that bleeding time in 32 male volunteers is increased from $69.33 \pm 4.94$ (mean \pm SEM) to $107.66 \pm 4.76$ (mean \pm SEM) with a t-statistics of 7.124 and a very high significant statistical difference $(\mathrm{P}<0.0005)$ after aspirin administration. The bleeding time in 105 females is increased from $73.03 \pm 1.89$ (mean \pm SEM) to $113.65 \pm 3.73$ (mean \pm SEM) with a t-statistics of 3.130 and a high significant statistical difference $(\mathrm{P}<0.0025)$ after aspirin administration. This clearly indicates that aspirin alters the bleeding time more in males as compared to females.

Table 3: Effect of aspirin on bleeding times in male and female.

\begin{tabular}{|c|c|c|c|c|}
\hline \multirow[t]{2}{*}{ Sex } & \multicolumn{2}{|c|}{ Bleeding Time } & \multirow[t]{2}{*}{ t-statistics } & \multirow[t]{2}{*}{ Significance } \\
\hline & $\begin{array}{l}\text { Before } \\
\text { Aspirin }\end{array}$ & $\begin{array}{l}\text { After } \\
\text { Aspirin }\end{array}$ & & \\
\hline Male & $\begin{array}{l}69.33 \pm \\
4.94(32)^{*}\end{array}$ & $\begin{array}{l}107.66 \pm \\
4.76(32)\end{array}$ & $\mathrm{t}=7.124$ & $\mathrm{P}<0.0005$ \\
\hline Female & $\begin{array}{l}73.03 \pm \\
1.89(105)\end{array}$ & $\begin{array}{l}113.65 \pm \\
3.73(105)\end{array}$ & $\mathrm{t}=3.130$ & $\mathrm{P}<0.0025$ \\
\hline
\end{tabular}

* Mean \pm SEM (Number of volunteers)

Table 4 compares the bleeding time in two phases of menstrual cycle. In follicular phase, bleeding time in 44 females is $70.22 \pm 2.90$ (mean \pm SEM). In luteal phase, this time in 29 females is $81.13 \pm 4.26$ (mean \pm SEM). Both the results are statistically significant different $(\mathrm{P}<0.05)$.

Table 4: Bleeding time before aspirin administration in different phases of menstrual cycle.

\begin{tabular}{|lcl|}
\hline Phase & Bleeding time & Significance \\
\cline { 1 - 2 } Follicular & $70.22 \pm 2.90(44) *$ & \\
\cline { 1 - 2 } Luteal & $81.13 \pm 4.26(29)$ & \\
\cline { 1 - 2 } & $*$ Mean \pm SEM (Number of volunteers)
\end{tabular}

Table 5 compares the bleeding time in two phases of menstrual cycle after aspirin administration. In follicular phase, bleeding time in 44 females, comes to be $109.65 \pm 3.82$ (mean \pm SEM). In luteal phase, this time in 29 females is increased up to117.95 \pm 7.49 (mean \pm SEM). Both the results has statistically insignificant difference $(\mathrm{P}>0.05)$

Table 5: Bleeding time after aspirin administration in different phases of menstrual cycle.

\begin{tabular}{|lll|}
\hline Phase & Bleeding time & Significance \\
\hline Follicular & $109.65 \pm 3.82(44) *$ & P $>0.05$ \\
\hline Luteal & $117.95 \pm 7.49(29)$ & \\
\hline \multicolumn{4}{|c|}{$*$ Mean \pm SEM (Number of volunteers) } \\
\hline
\end{tabular}

Table 6 represents the comparison of bleeding time in different phases of menstrual cycle in females, before and after aspirin administration. Before aspirin, mean bleeding time in 44 females in follicular phase is $70.22 \pm 2.90$ (mean \pm SEM) and in 29 females in luteal 
phase is $81.13 \pm 4.26($ mean \pm SEM). After aspirin, this time is increased in females in follicular phase up to $109.65 \pm 3.82($ mean \pm SEM $)$ and in females in luteal phase up to $117.95 \pm 7.49$ (mean \pm SEM). The difference between bleeding times before giving aspirin is statistically significant $(\mathrm{P}<0.02)$ which becomes insignificant $(\mathrm{P}<0.20)$ after aspirin administration.

\section{Table 6: Effect of aspirin on bleeding time during different phases of menstrual cycle in female.}

\begin{tabular}{|c|c|c|c|c|}
\hline \multirow[t]{2}{*}{ Time } & \multicolumn{2}{|c|}{ Menstrual Cycle } & \multirow[t]{2}{*}{ t-statistics } & \multirow[t]{2}{*}{ Significance } \\
\hline & $\begin{array}{l}\text { Follicular } \\
\text { Phase }\end{array}$ & $\begin{array}{l}\text { Luteal } \\
\text { Phase }\end{array}$ & & \\
\hline $\begin{array}{l}\text { Before } \\
\text { Aspirin }\end{array}$ & $\begin{array}{l}70.22 \pm \\
2.90(44)^{*}\end{array}$ & $\begin{array}{l}81.13 \pm \\
4.26(29)\end{array}$ & $\mathrm{t}=2.118$ & $\mathrm{P}<0.02$ \\
\hline $\begin{array}{l}\text { After } \\
\text { Aspirin }\end{array}$ & $\begin{array}{l}109.65 \pm \\
3.82(44)\end{array}$ & $\begin{array}{l}117.95 \pm \\
7.49(29)\end{array}$ & $\mathrm{t}=0.985$ & $\mathrm{P}<0.20$ \\
\hline
\end{tabular}

$*$ Mean \pm SEM (Number of volunteers)

Table 7 further elaborates the effect of aspirin on bleeding time in the two phases of menstrual cycle. After aspirin administration, mean bleeding time in 44 females in follicular phase is increased from 70.22 \pm 2.90 $($ mean \pm SEM) to $109.65 \pm 3.82($ mean \pm SEM) and of 22 females in luteal phase from $81.13 \pm 4.26$ (mean \pm SEM) to $117.95 \pm 7.49$ (mean \pm SEM). The effect of aspirin on bleeding time is relatively more pronounced in follicular phase as represented by t statistics.

Table 7: Effect of aspirin on bleeding time in different phases of menstrual cycle in female.

\begin{tabular}{|c|c|c|c|c|}
\hline \multirow[t]{2}{*}{ Phase } & \multicolumn{2}{|c|}{ Bleeding Time } & \multirow[t]{2}{*}{ t-statistics } & \multirow[t]{2}{*}{ Significance } \\
\hline & $\begin{array}{l}\text { Before } \\
\text { Aspirin }\end{array}$ & $\begin{array}{l}\text { After } \\
\text { Aspirin }\end{array}$ & & \\
\hline Follicular & $\begin{array}{l}70.22 \pm \\
2.90(44) *\end{array}$ & $\begin{array}{l}109.65 \pm \\
3.82(44)\end{array}$ & $\mathrm{t}=11.246$ & $\mathrm{P}<0.0005$ \\
\hline Luteal & $\begin{array}{l}81.13 \pm \\
4.26(29)\end{array}$ & $\begin{array}{l}117.95 \pm \\
7.49(29)\end{array}$ & $t=9.621$ & $\mathrm{P}<0.0005$ \\
\hline
\end{tabular}

* Mean \pm SEM (Number of volunteers)

\section{DISCUSSION}

Drug and hormone interactions have been proved in various studies. Aspirin and sulfamethoxazoletrimethoprim suppresses thyroid hormone concentration in dogs. 3,4

Lithium salt also has similar depressive effects on thyroid function. ${ }^{5}$ Diazepam reduces cortisol levels ${ }^{6}$, while chlorpromazine increases prolactin in body. ${ }^{7}$ So, different amount of major hormones in the two genders leads to sex based different responses to certain drugs. For instance, antipsychotics and beta blockers are more effective in women $^{8}$, males are more sensitive to propofol $^{9}$ and pentazocine produces more post-operative analgesia in females. ${ }^{10}$ Our study has further supported these differences by studying the sex related disproportionate effects of aspirin on bleeding time.

Bleeding time increases significantly in males as compared to females after aspirin administration possibly because of testosterone, which up regulates the thromboxane A2 receptors and platelet aggregability. ${ }^{11}$ This means male are more sensitive to thromboxane inhibition of aspirin because of greater number of receptors and hence more activity, thus leading to more bleeding as compared to females. This effect is further supported by reduced level of testosterone in older adults after castration which reduces thromboxane A2 receptor density and platelet aggregation potential. ${ }^{12}$

Furthermore, androgen at physiological levels inhibits oxidative-stress-induced platelet aggregation by reducing thromboxane release from platelets. ${ }^{13}$ Augmentation of this effect by aspirin would decrease the platelet assembly even further, leading to more bleeding in males. Moreover, prostaglandin F2 alpha is a platelet aggregator inhibitor that produces its effect even in aspirin treated cells $^{14}$ is present in greater amount in males ${ }^{15}$, hence producing more significant bleeding as compared to the opposite gender.

Increased cyclooxygenase activity and thromboxane production in males as compared to females ${ }^{15}$ also suggest the significant effect of aspirin in the former group.

However, result of increased bleeding time in females was less significant than males.

Studies have shown that female sex hormones exert negative effect on platelet aggregation ${ }^{16-18}$, but the effect was not remarkably increased after aspirin administration in our research, possibly because of the females being partial responders of $\operatorname{aspirin}^{19}$ or some other compensatory mechanism in their body not yet known. For instance, cyclooxygenase activity was found to be higher after overiectomy but lower after castration ${ }^{20}$, indicating the probable role of female sex hormones in depressing cyclooxygenase activity. Contradictory to this phenomenon is the research proving an increased production of prostacyclin (PG-I2) by up regulating COX-2 activity ${ }^{21}$, supporting a normally increased bleeding time in females (Table 1), and at the same time supporting decreased effect of aspirin which also inhibits the production of prostacyclin, a potent platelet aggregator inhibitor.

Our research also compared the bleeding time in different phases of menstrual cycle after considering the fluctuations in female hormones during different phases. Data showed more bleeding in the follicular phase of the cycle, characterized by increase level of estradiol. Likely cause might be the lower platelet aggregability and higher fibrinolytic activity in the follicular phase. ${ }^{22}$ Since, estradiol inhibits platelet aggregability by increasing nitric oxide ${ }^{23}$, the effect of aspirin further reduces the 
aggregation in the follicular phase. Literature does not support any significant effect of progesterone on bleeding time.

\section{CONCLUSION}

Thus, it can be concluded that response to aspirin is dependant on gender, which must be taken into account when administering aspirin to the patient. Lower doses in males producing the same effect as little higher doses in females can reduce the incidence of toxicity.

\section{Funding: None}

Conflict of interest: None declared

Ethical approval: Approved by the university ethical committee

\section{REFERENCES}

1. Bowry AD, Brookhart MA, Choudhry NK. Metaanalysis of the efficacy and safety of clopidogrel plus aspirin as compared to antiplatelet monotherapy for the prevention of vascular events. Am J Cardiol 2008;101(7):960-6.

2. Flower R. What are all the things that aspirin does? BMJ 2003 September 13;327(7415):572-3.

3. Panciera DL, Refsal KR, Sennello KA. Effects of deracoxib and aspirin on serum concentrations of thyroxine, 3,5,3'-triiodothyronine, free thyroxine, and thyroid-stimulating hormone in healthy dogs. Am J Vet Res. 2006 Apr;67(4):599-603.

4. Frank LA, Hnilica KA, May ER, et al. Effects of sulfamethoxazole-trimethoprim on thyroid function in dogs. Am J Vet Res.2 005 Feb;66(2):256-9.

5. Kibirige D, Luzinda K, Ssekitoleko R. Spectrum of lithium induced thyroid abnormalities: a current perspective; Thyroid Res. 2013 Feb 7;6(1):3. doi: 10.1186/1756-6614-6-3.

6. Manthey L, Giltay EJ, van Veen T, et al. Long-term benzodiazepine use and salivary cortisol: the Netherlands Study of Depression and Anxiety (NESDA). J Clin Psychopharmacol. 2010 Apr;30(2):160-8.

7. Suzuki Y, Sugai T, Fukui N, et al. Differences in plasma prolactin levels in patients with schizophrenia treated on monotherapy with five second-generation antipsychotics; Schizophr Res. 2013 Apr;145(1-3):116-9.

8. Heather P. Whitley, Wesley Lindsey. Sex-Based Differences in Drug Activity. Am Fam Physician. 2009 Dec 1;80(11):1254-1258.

9. Pleym H, Spigset O, Kharasch ED, et al. Gender differences in drug effects: implications for anesthesiologists. Acta Anaesthesiol Scand 2003;47:241-59.

10. Gear RW, Miaskowski C, Gordon NC, Paul SM, Heller PH, Levine JD. Kappa-opioids produce significantly greater analgesia in women than in men. Nat Med. 1996 Nov;2(11):1248-50.
11. Ajayi AA, Mathur R, Halushka PV.Testosterone increases human platelet thromboxane A2 receptor density and aggregation responses. Circulation. 1995 Jun 1;91(11):2742-7.

12. Ajayi AA, Halushka PV. Castration reduces platelet thromboxane A2 receptor density and aggregability. QJM. 2005 May;98(5):349-56.

13. Li S, Li X, Li J, et al. Inhibition of oxidative-stressinduced platelet aggregation by androgen at physiological levels via its receptor is associated with the reduction of thromboxane A2 release from platelets. Steroids. 2007 Nov;72(13):875-80.

14. Armstrong RA, Jones RL, Wilson NH. Mechanism of the inhibition of platelet aggregation produced by prostaglandin F2 alpha. Prostaglandins. 1985 Apr;29(4):601-10.

15. R.M. Gutierrezcernosek, Linda M. Morrill, Lawrence Levine. Prostaglandin $\mathrm{F}_{2 \alpha}$ levels in peripheral sera of man. Prostaglandins 1972;1:7180.

16. M. Johnson, E. Ramey, P. W. Ramwell. Androgenmediated sensitivity in platelet aggregation. AJP Heart April 1, 1977 vol. 232 no. 4 H381-H385.

17. Muthuvel Jayachandran, Hiroya Okano, Ritu Chatrath. Sex-specific changes in platelet aggregation and secretion with sexual maturity in pigs. Journal of Applied Physiology October 1, 2004 vol. 97 no. 4 1445-1452.

18. M. Wakasugi, T. Noguchi, Y-I.Kazama, et al. The effects of sex hormones on the synthesis of prostacyclin $\left(\mathrm{PGI}_{2}\right)$ by vascular tissues; Yamanashiken 409-38, Japan.

19. Cavallari LH, Helgason CM, Brace LD, et al. Sex difference in the antiplateleteffect ofaspirin in patients with stroke; Ann Pharmacother. 2006 May;40(5):812-7.

20. Morikawa M, Kojima $\mathbf{T}$, Inoue $\mathbf{M}$, et al. Sex difference in the effect of aspirin on rat platelet aggregation and arachidonic acid metabolism. Jpn J Pharmacol. 1985 Apr;37(4):317-23.

21. Morikawa $\mathbf{M}$, Kojima $\mathrm{T}$, Inoue $\mathbf{M}$, et al. Sex difference in the effect of aspirin on intracellular $\mathrm{Ca} 2+$ mobilization and thromboxane $\mathrm{A} 2$ production in rat platelets. Jpn J Pharmacol. 1986 Mar;40(3):463-8.

22. Gaule A, Balsubramanian B, Kharche JS, et al. Platelet Aggregability and Fibrinolytic Activity In Different Phases Of Menstrual Cycle. NJIRM. 2012;3(4):80-5.

23. Nakano Y, Oshima T, Matsuura H, Kajiyama G, Kambe M. Effect of 17beta-estradiol on inhibition of platelet aggregation in vitro is mediated by an increase in NO synthesis. Arterioscler Thromb Vasc Biol. 1998 Jun;18(6):961-7.

doi:10.5455/2319-2003.ijbcp20131005

Cite this article as: Aftab MT, Shakeel S, Tariq H, Shaikh S. Sex hormones alter the effect of aspirin on bleeding. Int J Basic Clin Pharmacol 2013;2:537-40. 